\title{
Nitrogen deposition threatens species richness of grasslands across Europe
}

Carly J. Stevens, Cecilia Duprè, Edu Dorland, Cassandre Gaudnik, David J.G. Gowing, Albert Bleeker, Martin Diekmann, Didier Alard, Roland Bobbink, David Fowler, Emmanuel Corcket, J. Owen Mountford, Vigdis Vandvik, Per Arild Aarrestad, Serge Muller, Nancy B. Dise 


\title{
Nitrogen deposition threatens species richness of grasslands across Europe
}

\author{
Carly J. Stevens $^{\mathrm{a}, \mathrm{b}, *}$, Cecilia Duprè ${ }^{\mathrm{c}}$, Edu Dorland ${ }^{\mathrm{d}, 1}$, Cassandre Gaudnik ${ }^{\mathrm{e}}$, David J.G. Gowing ${ }^{\mathrm{a}}$, \\ Albert Bleeker ${ }^{\mathrm{f}}$, Martin Diekmann ${ }^{\mathrm{c}}$, Didier Alard ${ }^{\mathrm{e}}$, Roland Bobbink ${ }^{\mathrm{g}}$, David Fowler ${ }^{\mathrm{h}}$, \\ Emmanuel Corcket ${ }^{\mathrm{e}}$, J. Owen Mountford ${ }^{\mathrm{i}}$, Vigdis Vandvik ${ }^{\mathrm{j}}$, Per Arild Aarrestad ${ }^{\mathrm{k}}$, \\ Serge Muller ${ }^{1}$, Nancy B. Dise ${ }^{\mathrm{m}}$
}

${ }^{a}$ Department of Life Sciences, The Open University, Walton Hall, Milton Keynes MK7 6AA, UK

${ }^{\mathrm{b}}$ Lancaster Environment Centre, Lancaster University, Lancaster LA1 4YQ UK

${ }^{\mathrm{c}}$ Institute of Ecology, FB 2, University of Bremen, Leobener Str., DE-28359 Bremen, Germany

d Section of Landscape Ecology, Department of Geobiology, Utrecht University, P.O. Box 80084, 3508 TB Utrecht, The Netherlands

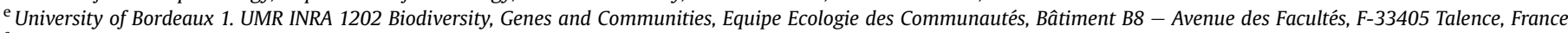

${ }^{\mathrm{f}}$ Department of Air Quality E Climate Change, Energy Research Centre of the Netherlands, P.O. Box 1, 1755 ZG Petten, The Netherlands

${ }^{\mathrm{g}}$ B-WARE Research Centre, Radboud University, P.O. Box 9010, 6525 ED Nijmegen, The Netherlands

${ }^{\mathrm{h}}$ NERC Centre for Ecology and Hydrology, Bush Estate, Penicuik, Midlothian EH26 OQB, UK

${ }^{\mathrm{i}}$ NERC Centre for Ecology \& Hydrology, MacLean Building, Benson Lane, Crowmarsh Gifford, Wallingford, Oxfordshire OX10 8BB, UK

${ }^{\mathrm{j}}$ Department of Biology, University of Bergen, Box 7800, N-5020 Bergen, Norway

${ }^{\mathrm{k}}$ Norwegian Institute for Nature Research, NO-7485 Trondheim, Norway

${ }^{1}$ Laboratoire des Interactions Ecotoxicologie, Biodiversité et Ecosystèmes (LIEBE), UMR CNRS 7146, U.F.R. Sci. F.A., Campus Bridoux, Université Paul Verlaine,

Avenue du Général Delestraint, F-57070 Metz, France

${ }^{\mathrm{m}}$ Department of Environmental and Geographical Science, Manchester Metropolitan University, Manchester M1 5GD, UK

Atmospheric nitrogen deposition is reducing biodiversity in grasslands across Europe.

\section{A R T I C L E I N F O}

\section{Article history:}

Received 17 March 2010

Received in revised form

1 June 2010

Accepted 4 June 2010

\section{Keywords:}

Acid grasslands

Acidification

Atmospheric nitrogen deposition

Soil pH

Species richness

\begin{abstract}
A B S T R A C T
Evidence from an international survey in the Atlantic biogeographic region of Europe indicates that chronic nitrogen deposition is reducing plant species richness in acid grasslands. Across the deposition gradient in this region $\left(2-44 \mathrm{~kg} \mathrm{~N} \mathrm{ha}^{-1} \mathrm{yr}^{-1}\right)$ species richness showed a curvilinear response, with greatest reductions in species richness when deposition increased from low levels. This has important implications for conservation policies, suggesting that to protect the most sensitive grasslands resources should be focussed where deposition is currently low. Soil $\mathrm{pH}$ is also an important driver of species richness indicating that the acidifying effect of nitrogen deposition may be contributing to species richness reductions. The results of this survey suggest that the impacts of nitrogen deposition can be observed over a large geographical range.
\end{abstract}

(C) 2010 Elsevier Ltd. All rights reserved.

\section{Introduction}

In recent years the global threat posed by atmospheric nitrogen (N) deposition has become clear (Sala et al., 2000; Galloway et al., 2008; Bobbink et al., 2010), but to date, impacts of $\mathrm{N}$ deposition on the biodiversity and ecosystem function in semi-natural environments have only been demonstrated at local and national scales (Stevens et al., 2004; Jones et al., 2004; Smart et al., 2005; Maskell et al., 2010). The deposition of reactive $\mathrm{N}$ has more than doubled

\footnotetext{
* Corresponding author.

E-mail address: c.j.stevens@open.ac.uk (C.J. Stevens).

1 Current address: Staatsbosbeheer, Postbus 1300, 3970 BH Driebergen, The Netherlands.
}

over the last one hundred years as a result of agricultural intensification and increased burning of fossil fuels by traffic and industry (Galloway et al., 2004; Fowler et al., 2005). Atmospheric deposition of reactive $\mathrm{N}$ has the potential to enrich the $\mathrm{N}$ content of soils, resulting in increased plant growth and hence competition for light (Bobbink et al., 1998; Hautier et al., 2009) and other resources, and to acidify soils reducing the number of species that can tolerate these conditions and coexist (Schuster and Diekmann, 2003). Globally, the deposition of reactive $\mathrm{N}$ is predicted to increase in the future due to the expanding global population leading to increased demand for food and increased use of fossil fuels (Tilman et al., 2002; Dentener et al., 2006). The potential loss of biodiversity as a result of $\mathrm{N}$ deposition has important implications for both environmental and agricultural policy. 
In 2004, Stevens et al. identified a linear decline in plant species richness of acid grasslands in Great Britain associated with long-term chronic $\mathrm{N}$ deposition. This has since been demonstrated in other habitats in Great Britain such as heathlands, calcareous grasslands and dune grasslands (Maskell et al., 2010; Jones et al., 2004). However, until now there has been little research showing a) what happens at levels of deposition lower than those found in Great Britain b) how important $\mathrm{N}$ deposition is as a driver of species richness and c) whether the losses of biodiversity reported by Stevens et al. (2004) are occurring on a larger, international scale.

To address these research needs, we surveyed 153 semi-natural acid grasslands belonging to the Violion caninae alliance (Schwickerath, 1944) on a transect across the Atlantic biogeographic zone of Europe with total atmospheric $\mathrm{N}$ deposition ranging from 2.4 to $43.5 \mathrm{~kg} \mathrm{~N}^{-1} \mathrm{yr}^{-1}$ (Fig. 1), covering much of the range of deposition found in the industrialised world. V. caninae grasslands are widespread across western Europe, but changes in land use have decreased their cover in some regions (Ellenberg, 1996). They are economically valuable providing a number of ecosystem services including extensive sheep and cattle grazing in some regions, and are important for biodiversity supporting a range of plants, invertebrates and mammals. These grasslands are dominated by species such as Agrostis capillaris, Festuca ovina and rubra, Potentialla erecta and Galium saxatile, typically with a dense sward where species are intimately mixed.

Grasslands were surveyed in Atlantic regions of Great Britain, Isle of Man, Ireland, France, Germany, Belgium, the Netherlands, Denmark, Sweden and Norway (Fig. 1). All of the grasslands were surveyed between 2002 and 2007 using a consistent methodology; all were unfertilised and many were in areas protected for nature conservation.

\section{Materials and methods}

2.1. Field methodology

Between 2002 and 2007153 acid grasslands belonging to the $V$. caninae alliance (Schwickerath, 1944) were surveyed within the Atlantic biogeographic zone of Europe. All grasslands were surveyed between May and September. The survey consisted of: nine grasslands in Belgium, three grasslands in Denmark, twenty-five grasslands in France, twelve grasslands in Germany, eleven grasslands in Ireland, Northern Ireland and the Isle of Man, seven grasslands in the Netherlands, nine grasslands in Norway, four grasslands in Sweden and seventyseven grasslands in Great Britain. The large number of sites surveyed in Great Britain derives from the intensive national survey of the earlier work and the fact that $V$. caninae grasslands cover a much larger area than in other countries in the study (Stevens et al., 2004).

The grasslands were selected to cover the range of atmospheric $\mathrm{N}$ deposition in Europe and to give a good range of sites at different latitudes and longitudes for different deposition values. Grasslands surveyed were not agriculturally improved or in the vicinity of a point source of $\mathrm{N}$ and were managed by grazing or cutting. Within each site, five randomly located $4 \mathrm{~m}^{2}$ quadrats were surveyed, avoiding areas of vegetation belonging to a different community (e.g. areas of shrub) or were strongly affected by animals, tracks and paths, or were in the rain shadows of trees or hedges. Within each quadrat all vascular plants and bryophytes were identified to species level and percent cover was estimated by eye. A description of the site was made including latitude, longitude, aspect, slope, extent of grassland, soil depth and surrounding vegetation communities.

Soil samples were collected from each quadrat. Topsoil samples $(0-10 \mathrm{~cm}$ below the litter layer) were taken from two opposing corners of the quadrat using a trowel and bulked to give one sample per quadrat. Subsoil samples $(20-30 \mathrm{~cm}$ deep or as deep as possible in shallow soil) were taken from the centre of the quadrat using a $5 \mathrm{~cm}$ diameter soil auger. All soil samples were kept cool during transit and air dried on return to the laboratory.

For each site, $\mathrm{N}$ and sulphur deposition data were modelled using the EMEPbased IDEM model (Pieterse et al., 2007) or national deposition models depending on which were available in each of the countries surveyed. Full details are given below. Meteorological data were obtained from the European Space Agency Monitoring Agriculture with Remote Sensing (MARS) unit (Monitoring Agricultural Resources, 2009); ten year averages were calculated for each site for mean annual potential transpiration from crop canopy, mean minimum daily temperature, mean maximum daily temperature and mean annual rainfall. Radiation index was calculated based on aspect, slope and latitude according to Oke (1987).

\subsection{Laboratory methodology}

All analyses were conducted on air-dried soils due to the large number and geographical spread of sites being surveyed (MAFF, 1986). Soil pH was determined using a pH probe in a 1:5 soil and deionised water mixture.

Nitrate, ammonium, calcium and aluminium concentrations were determined using two different methods. For samples collected in 2002 and 2003 from Great Britain, soils were extracted with $1 \mathrm{M} \mathrm{KCl}$ and analysed using an ion chromatograph. Soil samples collected in 2007 were shaken with $0.4 \mathrm{M} \mathrm{NaCl}$ and analysed using an auto-analyser. All extracts were determined using a 1:10 soil and extractant mixture. Aluminium and calcium concentrations were determined using an ICP-MS. Stored soil samples from the earlier survey were analysed using the methodology of the later survey showing that results of the two extraction methodologies were comparable. Phosphorus availability was determined using a standard Olsen extraction and colourometric determination (MAFF, 1986). Total C and N content of the soil was determined using a $\mathrm{CN}$ elemental analyser by combustion and gas detection.

\subsection{Deposition models}

For all of the sites visited, the best available deposition model was used for estimating the deposition of nitrogen and sulphur (S), resulting in some variation in the models used. National models were used for Germany (Gauger et al., 2002), the Netherlands (Van Jaarsveld, 1995, 2004; Asman and van Jaarsveld, 2002) and Great Britain (NEGTAP, 2001). For all other countries the EMEP-based IDEM (Pieterse et al., 2007) models were used. The different model use similar approaches to model reduced and oxidised deposition. Comparison between the models showed that these models provided the best estimates of deposition across the region. For all of the models, deposition was calculated as a three-year average to provide a more robust estimate of longer-term nitrogen inputs.

\subsection{Statistical analysis}

For all analyses mean values from the five samples per site were used. Simple regression and forward and backward multiple regressions were conducted using SPSS v17. All variables were checked for normality and corrected if necessary (Table 1) and strongly inter-correlated independent variables $(r>0.5)$ were removed from the models. The variables to be retained were selected based on ecological relevance. Soil ammonia concentration and plant available P concentration were highly skewed and correction did not result in a normal distribution. In these cases the model was run with and without these variables included. In each case, results did not differ between model runs so they were excluded from the analysis. The regression tree was analysed in $\mathrm{R}$ according to the method set out in Crawley (2007) and variance partitioning using stepwise multiple regression were analysed in Minitab.

\section{Results}

Examining the relationship between atmospheric $\mathrm{N}$ deposition and species richness shows a significant negative linear relationship (linear regression $r^{2}=0.36, p<0.001$ ). The distribution of sampling sites differs between countries and Great Britain contributes a large proportion of the overall data set. However, when data for Great Britain is removed from the regression model, the relationship remains significant $\left(r^{2}=0.28, p<0.001\right)$. Analysis of covariance shows that the intercept of the regression line for mainland European species richness differs significantly from the regression line for the Great Britain $(p<0.001)$, but gradients of the two regression lines for the relationship between $\mathrm{N}$ deposition and species richness are not significantly different.

The relationship between $\mathrm{N}$ deposition and species richness is better fitted with a negative exponential curve giving an $r^{2}$ of 0.40 $(p<0.0001$, Fig. 1$)$. This shows a potentially greater loss of species richness when deposition increases from a low background level than a high level.

Most of the decline in species richness is accounted for by a reduction in forb species richness, with grass richness and bryophyte richness showing weaker but still significant negative relationships with $\mathrm{N}$ deposition (forbs: $r 2=0.31, p<0.001$ 

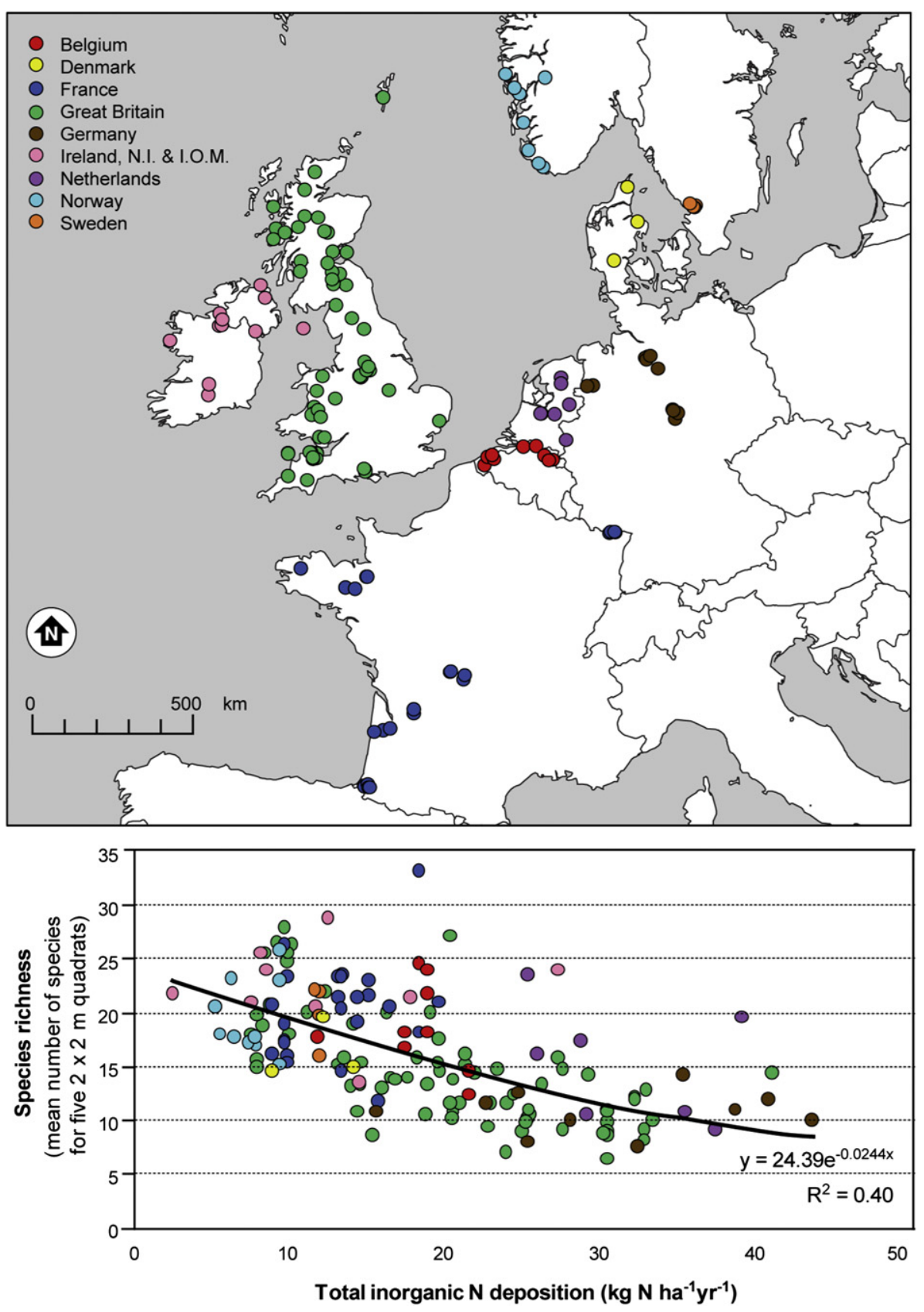

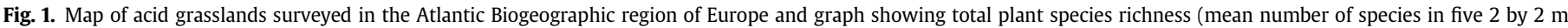

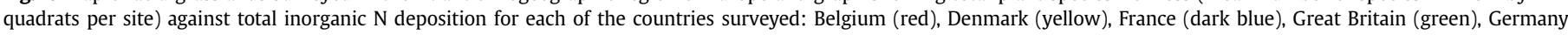

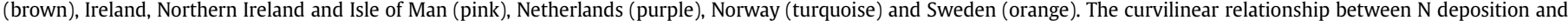
species richness is shown. (For interpretation of the references to colour in this figure legend, the reader is referred to the web version of this article).

(exponential relationship) grass: $r^{2}=0.27, p<0.001$ (linear relationship), bryophyte: $r^{2}=0.05, p<0.005$ (linear relationship); Fig. 2).

Multiple regression (forward and backward stepwise regression) was used to identify additional drivers of species richness in this data set. Correlated variables were removed and corrections for non-normality applied, leaving a set of sixteen variables for analysis (Table 1). Multiple regression showed that total inorganic $\mathrm{N}$ deposition, topsoil $\mathrm{pH}$, radiation index and extractable soil nitrate concentration (log transformed for normality) explained a total of $55 \%$ of the variation in species richness (Eq. (1)):

$$
\begin{aligned}
\text { Species richness }= & 0.210+5.038(\text { Topsoil } \mathrm{pH}) \\
& -0.243(\mathrm{~N} \text { deposition }) \\
& -3.978(\text { Radiation index }) \\
& -0.304\left(\ln \mathrm{NO}_{3}^{-}\right)
\end{aligned}
$$

Topsoil pH showed the strongest linear correlation with species richness, with an $r^{2}$ of 0.38 ( $p<0.001$ ) (Fig. 3a). As topsoil pH is influenced by site physical characteristics and $\mathrm{N}$ deposition, this correlation may be related to acidification of the soils, but the approach does not distinguish between the sources of acidification 
Table 1

Variables recorded in this study. Variables entered into the regression models are shown in bold. Some variables had to be excluded due to correlation with other variables or data distributions that were too strongly skewed for analysis.

\begin{tabular}{|c|c|}
\hline Variable & Range \\
\hline \multicolumn{2}{|l|}{ Dependent variable } \\
\hline $\begin{array}{l}\text { Species richness (mean number of species per five } 4 \mathrm{~m}^{2} \\
\text { quadrats) }\end{array}$ & $6.4-33.2$ \\
\hline \multicolumn{2}{|l|}{ Deposition variables } \\
\hline $\begin{array}{l}\text { Total inorganic } \mathrm{N} \text { deposition } \\
\quad\left(\mathrm{kg} \mathrm{N} \mathrm{ha}^{-1} \mathrm{yr}^{-1}\right)\end{array}$ & $2.4-43.5$ \\
\hline $\begin{array}{l}\text { Total inorganic } S \text { deposition } \\
\quad\left(\mathbf{k g ~ N ~ h a - 1} \mathrm{yr}^{-1}\right)\end{array}$ & $2.2-19.6$ \\
\hline \multicolumn{2}{|l|}{ Geographical and physical variables } \\
\hline Longitude & $-9.951-13.25$ \\
\hline Latitude & $43.303-60.697$ \\
\hline Altitude (m) & $4-812(\operatorname{Ln})$ \\
\hline Inclination $\left({ }^{\circ}\right)$ & $0-60$ \\
\hline Aspect $\left({ }^{\circ}\right)$ & $0-350$ \\
\hline Vegetation height $(\mathrm{cm})$ & $1.5-40$ \\
\hline Radiation index & $-0.43-0.99$ \\
\hline Mean maximum daily temperature $\left({ }^{\circ} \mathrm{C}\right)$ & $6.8-18.8$ \\
\hline Mean minimum daily temperature $\left({ }^{\circ} \mathrm{C}\right)$ & $0.6-10.2$ \\
\hline Mean annual rainfall $(\mathrm{mm})$ & $498-1971$ \\
\hline Mean annual potential transpiration from canopy (mm) & $487-834$ \\
\hline \multicolumn{2}{|l|}{ Soil variables } \\
\hline Topsoil pH & $3.7-5.7$ \\
\hline Subsoil pH & $3.3-6.1$ \\
\hline Extractable aluminium concentration ( $\mathrm{mg} \mathrm{kg}^{-1}$ dry soil) & $2.3-1319(\mathrm{Ln})$ \\
\hline Extractable ammonium concentration ( $\mathrm{mg} \mathrm{kg}^{-1}$ dry soil) & $0-305$ \\
\hline Extractable nitrate concentration ( $\mathrm{mg} \mathrm{kg}^{-1}$ dry soil) & $0-172(\operatorname{Ln})$ \\
\hline Olsen $\mathrm{P}$ ( $\mathrm{mg} \mathrm{kg}^{-1}$ dry soil) & $0-86$ \\
\hline $\mathrm{C}(\%)$ & $0.03-40.63$ \\
\hline $\mathrm{N}(\%)$ & $0.09-22.89$ \\
\hline C:N ratio (\%/\%) & $8.9-30.5$ \\
\hline Ca:Al ratio $(\mathrm{g} / \mathrm{g})$ & $0.01-20.49$ \\
\hline \multicolumn{2}{|l|}{ Management variables } \\
\hline Management type & Cutting/grazing \\
\hline $\begin{array}{l}\text { Management intensity (estimated from standing } \\
\text { crop biomass) }\end{array}$ & $\begin{array}{l}\text { High, medium } \\
\text { and low }\end{array}$ \\
\hline
\end{tabular}

Variables that did not show a normal distribution were $\log (\mathrm{Ln})$ - transformed. which include sulphur deposition. Indeed, there is a significant relationship between soil $\mathrm{pH}$ and $\mathrm{N}$ deposition $\left(r^{2}=0.20\right.$, $p<0.001$ ) (Fig. 3b) although as a result of the variability of soil types in this study and the large amount of variation in soil $\mathrm{pH}$ that is independent of $\mathrm{N}$ deposition, it was not necessary to remove this variable from the analysis. There was also a significant correlation between soil $\mathrm{pH}$ and $\mathrm{S}$ deposition $\left(r^{2}=0.18, p<0.001\right)$.

A regression tree confirmed the primary importance of $\mathrm{N}$ deposition as a driver of species richness. The division in the regression shows that at high deposition (greater than $20.3 \mathrm{~kg} \mathrm{~N} \mathrm{ha}^{-1} \mathrm{yr}^{-1}$ ), topsoil $\mathrm{pH}$ is the next most significant variable, followed by soil nitrate concentration, but at deposition less than $20.3 \mathrm{~kg} \mathrm{~N} \mathrm{ha}^{-1} \mathrm{yr}^{-1}$, extractable aluminium concentration is the next most significant.

\subsection{Discussion and conclusions}

The results of this large-scale survey suggest that the impacts of $\mathrm{N}$ deposition can be observed over a large geographical range and are not restricted to Great Britain, as initially demonstrated by Stevens et al. (2006). Analysis of covariance shows that the gradients of the two regression lines for the relationship between $\mathrm{N}$ deposition and species richness are not significantly different, implying that the species richness of grasslands in the two regions are equally sensitive to $\mathrm{N}$ deposition.

The results of this investigation are consistent with those found by Dupre et al. (2010) who conducted a temporal analysis of changes in species richness in the same grassland type. They found that during the last 70 years, species richness in Great Britain, Germany and the Netherlands have all declined significantly in relation to estimated cumulative $\mathrm{N}$ deposition. These results provide further evidence for declines in species richness related to chronic atmospheric $\mathrm{N}$ deposition and support the use of a space for time substitution for detecting the effects of $\mathrm{N}$ deposition.

The curvilinear relationship found in this investigation implies that small increases in $\mathrm{N}$ deposition will have a larger impact when background deposition levels are low or moderate than when initial deposition levels are higher (above $20 \mathrm{~kg} \mathrm{~N}^{-1} \mathrm{yr}^{-1}$, reflecting the point for splitting the data identified in the regression

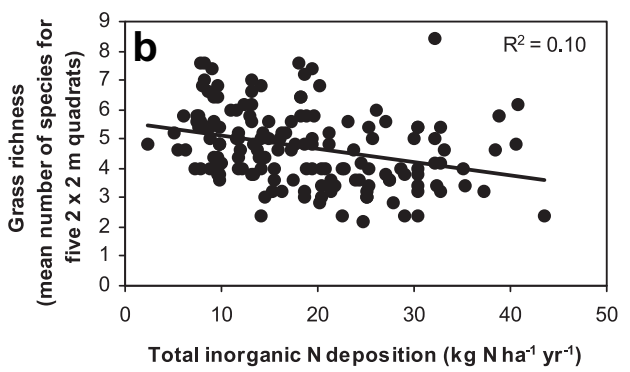

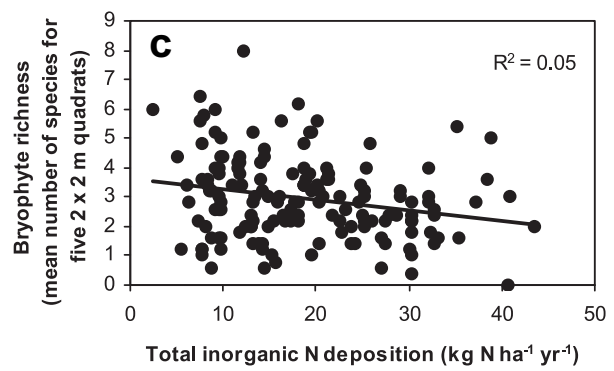

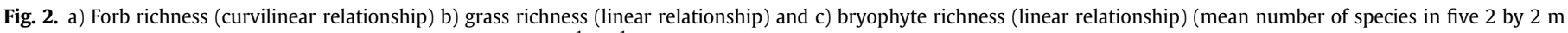
quadrats per site) against total inorganic $\mathrm{N}$ deposition $\left(\mathrm{kg} \mathrm{N} \mathrm{ha}^{-1} \mathrm{yr}^{-1}\right)$ for 153 acid grasslands surveyed in the Atlantic Biogeographic region of Europe. 

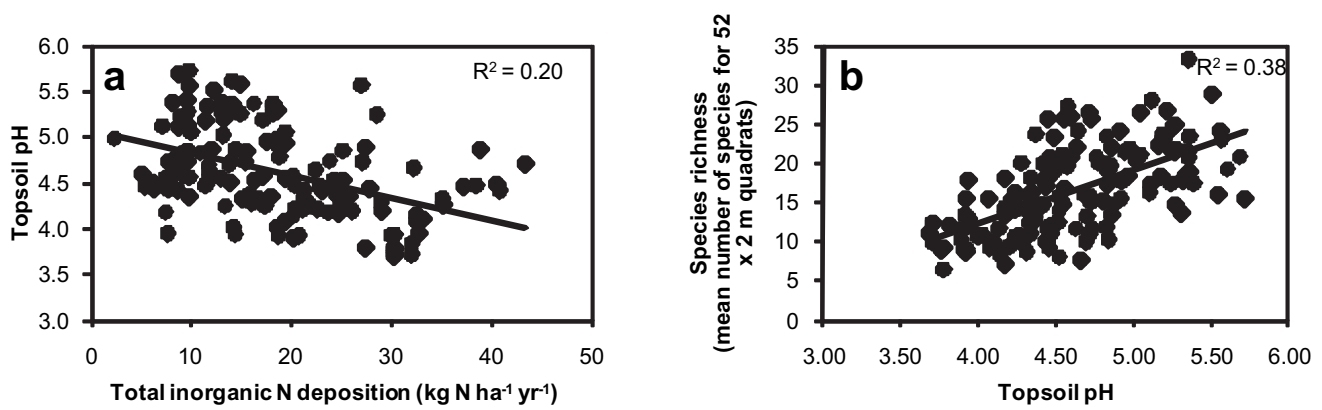

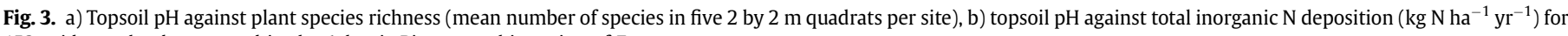
153 acid grasslands surveyed in the Atlantic Biogeographic region of Europe.

tree (Fig. 4)). These results support the experimental findings of Clark and Tilman (2008), who demonstrated the potential for species loss in prairie grasslands as a result of chronic low-level deposition. Below $20 \mathrm{~kg} \mathrm{~N} \mathrm{ha}^{-1} \mathrm{yr}^{-1}$, linear regression indicates that a deposition rate of $2.3 \mathrm{~kg} \mathrm{~N} \mathrm{ha}^{-1} \mathrm{yr}^{-1}$ reduces species richness by one species per $4 \mathrm{~m}^{2}$ quadrat. Above $20,3.5 \mathrm{~kg} \mathrm{~N} \mathrm{ha}^{-1} \mathrm{yr}^{-1}$ is tolerated before species richness is reduced by the same amount. Such a relationship indicates that at high deposition, many of the species sensitive to $\mathrm{N}$ deposition may have already declined leaving mainly the less nitrogen-sensitive species. These findings have important implications for conservation and restoration suggesting that to protect the most sensitive grasslands, resources should be focussed on protecting areas that are as yet relatively undamaged by $\mathrm{N}$ deposition, since the potential for species loss in these areas is greater (Emmett, 2007). There may also be important repercussions for the regulation of point source emissions of pollutants. Current legislation aims to maintain deposition below the critical load for $\mathrm{N}$ deposition (currently $10-20 \mathrm{~kg} \mathrm{~N} \mathrm{ha}^{-1} \mathrm{yr}^{-1}$ for acid grassland communities (Bobbink et al., 2003)), but the results of this study indicate that increasing deposition by very small amounts where background levels are low will result in reductions in species richness, even if the total deposition to the site (diffuse source plus point source) remains below the critical load. It is also important to note that even where the critical load is exceeded by background deposition, the addition of further $\mathrm{N}$ from a point source may still result in a reduction of species richness, even at high levels of deposition.

The majority of the decline in species richness is accounted for by a loss of forbs. This decline in forb species richness is the same trend as identified in earlier acid grassland surveys in Great Britain (Stevens et al., 2004, 2006, 2009) and is consistent with experimental $\mathrm{N}$ additions in other grassland types (e.g. Bobbink, 1991; Mountford et al., 1993; Wedin and Tilman, 1996) and historical studies (Dupre et al., 2010). The wedge shaped distribution observed for forbs and bryophytes indicates that at low deposition richness can be both high and low, but at high deposition high richness is not observed. A loss of species richness within the grassland sward potentially has wide implications for biodiversity further up the food chain (Throop and Lerdau, 2004; Weiss, 1999) as well as an impact on ecosystem functioning and ecosystem service provision.

The results of this study demonstrate the importance of soil $\mathrm{pH}$ as a driver of species richness. Of the variables examined, topsoil $\mathrm{pH}$ showed the strongest linear correlation with species richness, with an $r^{2}$ of $0.38(p<0.001)$ (Fig. 3a). As soil $\mathrm{pH}$ is reduced the forms and availability of nutrients and potentially toxic metals are affected, reducing the pool of species able to survive (Tyler, 2003). S deposition also shows a significant negative relationship with topsoil $\mathrm{pH}\left(r^{2}=0.18, p<0.001\right)$ showing that both $\mathrm{N}$ and $\mathrm{S}$ deposition (or their legacy) remain important drivers of soil $\mathrm{pH}$.
Variance partitioning allows assessment of the relative contributions of different groups of variables to the total variation in species richness. This analysis showed that both a site's geographical and physical characteristics (Table 1), and its management type and intensity, exclusively explain very little of the variation in species richness $\left(r^{2}=0.004\right.$ and 0.003 , respectively). These small numbers reflect the tightly defined plant community type and the similarities in management practices across the transect. Soil variables exclusively explain $13.9 \%$ of the variation in species richness and deposition variables explain $6.9 \%$ of the variation in species richness, indicating that $\mathrm{N}$ deposition modifies the response of the plant community to site characteristics. However, the potential for $\mathrm{N}$ deposition to influence soil variables means that these two sets could be considered together. The sum of the variation in species richness explained exclusively and variation explained by $\mathrm{N}$ deposition and soil in combination is $53 \%$ of the variation in species richness.

The regression tree (Fig. 4) sheds further light on the interaction between independent variables. In the regression tree, the first division is with $\mathrm{N}$ deposition, reflecting the importance of this variable as a driver of species richness with $\mathrm{pH}$ and aluminium as the next most significant variables. Aluminium may be a more important driver of species richness at low deposition because here, species intolerant of aluminium toxicity have yet to be eliminated by acidification. The acid substrate in these habitats means that availability of aluminium in the soil can change greatly with small changes in soil pH. Below this level of the regression tree, other variables become important. $\mathrm{pH}$ is clearly a very important driver of species richness in these grasslands and soil acidification

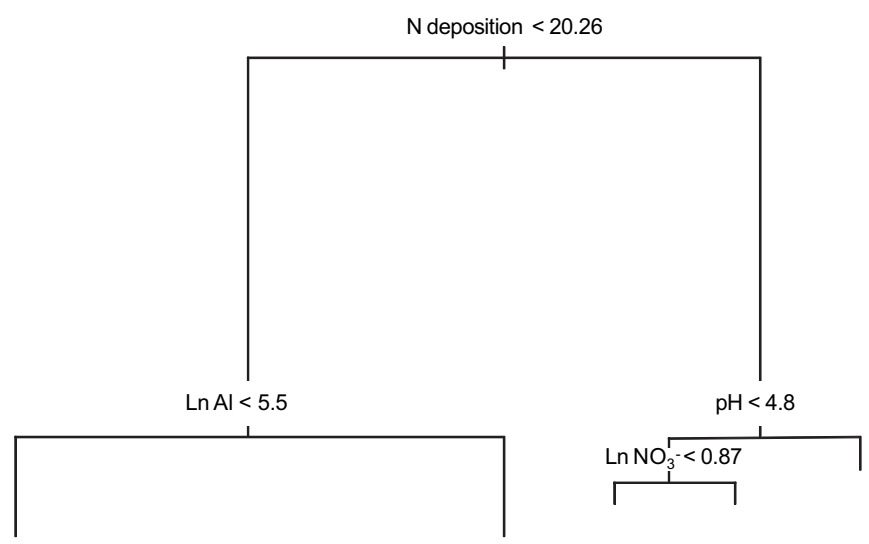

Fig. 4. Regression tree showing relationships between species richness and dependent variables (Table 1) using dichotomous partitioning criteria. Variables in the regression tree are: total inorganic $\mathrm{N}$ deposition $\left(\mathrm{kg} \mathrm{N} \mathrm{ha}^{-1} \mathrm{yr}^{-1}\right)$ ( $\mathrm{N}$ deposition), topsoil $\mathrm{pH}(\mathrm{pH})$, ln soil $\mathrm{KCl}$ extractable aluminium concentration $\left(\mathrm{mg} \mathrm{kg}^{-1}\right)(\ln \mathrm{Al})$ and $\ln$ soil $\mathrm{KCl}$ extractable nitrate concentration $\left(\mathrm{mg} \mathrm{kg}^{-1}\right)\left(\operatorname{ln~NO}_{3}^{-}\right)$. 
is likely to be playing an important role in the reduction of species richness. This was also found in analysis of temporal trends in species richness in relation to $\mathrm{N}$ deposition (Dupre et al., 2010).

\section{Conclusion}

The results of this large-scale survey indicate that chronic nitrogen deposition is reducing plant species richness in acid grasslands. Across the deposition gradient in the Atlantic biogeographic region of Europe species richness showed a curvilinear relationship with $\mathrm{N}$ deposition, with greatest differences in species richness where deposition increased from low levels. Given the large range over which we observe reduced species richness associated with high $\mathrm{N}$ deposition, the similar relationships that have been observed in other habitats (Maskell et al., 2010) and the results of experimental $\mathrm{N}$ additions in a wide range of habitats (e.g. Power et al., 1998; Morecroft et al., 1994; Jones et al., 2004; Pilkington et al., 2005) it is reasonable to assume that $\mathrm{N}$ deposition represents a global threat to the biodiversity of semi-natural ecosystems.

\section{Acknowledgements}

This project was funded by the European Science Foundation through the EURODIVERSITY-programme, and national funds were provided by DfG (Germany), NERC (United Kingdom) and NWO (The Netherlands) and INRA, ADEME and Aquitaine Region (France). We are grateful to everyone who assisted with field and laboratory work, and conservation agencies and land owners who gave permission for sampling.

\section{References}

Asman, W.A.H., van Jaarsveld, J.A., 2002. A variable-resolution transport model applied for NHx in Europe. Atmospheric Environment 26A, 445-464.

Bobbink, R., Ashmore, M., Braum, S., Fluckinger, W., Van den Wyngaert, I.J.J., 2003 Empirical nitrogen critical loads for natural and semi-natural ecosystems: 2002 update. In: Achermann, B, Bobbink, R (Eds.), Empirical Critical Loads for Nitrogen, Environmental Documentation No. 164 Air. Swiss Agency for Environment, Forest and Landscape SAEFL, Berne.

Bobbink, R., Hornung, M., Roelofs, J.G.M., 1998. The effects of air-borne nitrogen pollutants on species diversity in natural and semi-natural European vegetation. Journal of Ecology 86, 717-738.

Bobbink, R., Hicks, K., Galloway, J., Spranger, T., Alkemade, R., Ashmore, M. Bustamante, M., Cinderby, S., Davidson, E., Dentener, F., Emmett, B., Erisman, J. W., Fenn, M., Gilliam, F., Nordin, A., Pardo, L., De Vries, W., 2010. Global assessment of nitrogen deposition effects on terrestrial plant diversity: a synthesis. Ecological Applications 20, 30-59.

Bobbink, R., 1991. Effects of nutrient enrichment in Dutch chalk grassland. Journal of Applied Ecology 28, 28-41

Clark, C.M., Tilman, D., 2008. Loss of plant species after chronic low-level nitrogen deposition to prairie grasslands. Nature 451, 712-715.

Crawley, M.J., 2007. The R Book. John Wiley and Sons, Chichester

Dentener, F., Stevenson, D., Ellingsen, K., van Noije, T., Schultz, M., Amann, M. Atherton, C., Bell, N., Bergmann, D., Bey, I., Bouwman, L., Butler, T., Cofala, J., Collins, B., Drevet, J., Doherty, R., Eickhout, B., Eskes, H., Fiore, A., Gauss, M., Hauglustaine, D., Horowitz, L., Isaksen, I.S.A., Josse, B., Lawrence, M., Krol, M., Lamarque, J.F., Montanaro, V., Muller, J.F., Peuch, V.H., Pitari, G., Pyle, J., Rast, S. Rodriguez, J., Sanderson, M., Savage, N.H., Shindell, D., Strahan, S., Szopa, S., Sudo, K., Van Dingenen, R., Wild, O., Zeng, G., 2006. The global atmospheric environment for the next generation. Environmental Science \& Technology 40, 3586-3594.

Dupre, C., Stevens, C.J., Ranke, T., Bleeker, A., Peppler-Lisbach, C., Gowing, D.J.G., Dise, N.B., Dorland, E., Bobbink, R., Diekmann, M., 2010. Changes in species richness and composition in European acidic grasslands over the past 70 years: the contribution of cumulative atmospheric nitrogen deposition. Global Change Biology 16, 344-357.

Ellenberg, H., 1996. Vegetation Mitteleuropas mit den Alpen, fifth ed. Eugen Ulmer Stuttgart.

Emmett, B.A., 2007. Nitrogen saturation of terrestrial ecosystems: some recent findings and their implications for our conceptual framework. Water Air and Soil Pollution Focus 7, 99-109.

Fowler, D., Muller, J.B.A., Hayman, G., Vincent, K.J., 2005. Changes in the atmospheric deposition of acidifying compounds in the UK between 1986 and 2001. Environmental Pollution 137, 15-25.
Galloway, J.N., Dentener, F.J., Capone, D.G., Boyer, E.W., Howarth, R.W., Seitzinger, S. P., Asner, G.P., Cleveland, C.C., Green, P.A., Holland, E.A., Karl, D.M., Michaels, A.F., Porter, J.H., Townsend, A.R., Vorosmarty, C.J., 2004. Nitrogen cycles: past, present, and future. Biogeochemistry 70, 153-226.

Galloway, J.N., Townsend, A.R., Erisman, J.W., Bekunda, M., Cai, Z., Freney, J.R., Martinelli, L.A., Seitzinger, S.P., Sutton, M.A., 2008. Transformation of the nitrogen cycle: recent trends, questions and potential solutions. Science 320, 889-892.

Gauger, T., Anshelm, F., Schuster, H., Erisman, J.W., Vermeulen, A.T., Draaijers, G.P.J., Bleeker, A., Nagel, H.-D., 2002. Mapping of ecosystems specific long-term trends in deposition loads and concentrations of air pollutants in Germany and their comparison with critical loads and critical levels. In: Institut Fur Navigation. University of Stuttgart Germany.

Hautier, Y., Niklaus, P.A., Hector, A., 2009. Competition for light causes plant biodiversity loss after eutrophication. Science 324, 636-638.

Jones, M.L.M., Wallace, H.L., Norris, D., Brittain, S.A., Haria, S., Jones, R.E., Rhind, P.M., Reynolds, B.R., Emmett, B.A., 2004. Changes in vegetation and soil characteristics in coastal sand dunes along a gradient of atmospheric nitrogen deposition. Plant Biology 6, 598-605.

MAFF, 1986. The Analysis of Agricultural Materials, third ed.. Her Majesty's Stationary Office, London.

Maskell, L.C., Smart, S.M., Bullock, J.M., Thompson, K., Stevens, C.J., 2010. Nitrogen Deposition causes widespread species loss in British Habitats. Global Change Biology 16, 671-679.

Monitoring Agricultural Resources (MARS), 2009. European Commission Joint Research Centre URL. http://mars.jrc.it/mars/About-us/The-MARS-Unit.

Morecroft, M.D., Sellers, E.K., Lee, J.A., 1994. An experimental investigation into the effects of atmospheric deposition on two semi-natural grasslands. Journal of Ecology 82, 475-483.

Mountford, J.O., Lakhani, K.H., Kirkham, F.W., 1993. Experimental assessment of the effects of nitrogen addition under hay-cutting and aftermath grazing on the vegetation of meadows on a Somerset peat moor. Journal of Applied Ecology 30, 321-332.

NEGTAP, 2001. Transboundary Air Pollution: acidification, Eutrophication and Ground-level Ozone in the UK. CEH, Edinburgh.

Oke, T.R., 1987. Boundary Layer Climates. second ed., Methuen, New York.

Pieterse, G., Bleeker, A., Vermeulen, A.T., Wu, Y., Erisman, J.W., 2007. High resolution modelling of atmosphere-canopy exchange of acidifying and eutrophying components and carbon dioxide for European forests. Tellus 59B, 412-424.

Pilkington, M.G., Caporn, S.J.M., Carroll, J.A., Cresswell, N., Lee, J.A., Emmett, B.A., Johnson, D., 2005. Effects of increased deposition of atmospheric nitrogen on an upland Calluna moor: N and P transformation. Environmental Pollution 135 , 469-480.

Power, S.A., Ashmore, M.R., Cousins, D.A., 1998. Impacts and fate of experimentally enhanced nitrogen deposition on a British lowland heath. Environmental Pollution 102, 27-34.

Sala, O.E., Chapin, F.S., Armesto, J.J., Berlow, E., Bloomfield, J., Dirzo, R., HuberSanwald, E., Huenneke, L.F., Jackson, R.B., Kinzig, A., Leemans, R., Lodge, D.M., Mooney, H.A., Oesterheld, M., Poff, N.L., Sykes, M.T., Walker, B.H., Walker, M., Wall, D.H., 2000. Biodiversity - Global biodiversity scenarios for the year 2100 . Science 287, 1770-1774.

Schuster, B., Diekmann, M., 2003. Changes in species density along the soil pH gradient - evidence from German plant communities. Folia Geobotanica 38, 367-379.

Schwickerath, M., 1944. Das Hohe Venn und seine Randgebiete. Pflanzensoziologie $6,1-278$.

Smart, S.M., Bunce, R.G.H., Marrs, R.H., LeDuc, M., Firbank, L.G., Maskell, L.C., Scott, W.A., Thompson, K., Walker, K.J., 2005. Large-scale changes in the abundance of common higher plant species across Britain between 1978, 1990 and 1998 as a consequence of human activity: tests of hypothesised changes in trait representation. Biological Conservation 124, 355-371.

Stevens, C.J., Dise, N.B., Mountford, J.O., Gowing, D.J., 2004. Impact of nitrogen deposition on the species richness of grasslands. Science 303, 1876-1879.

Stevens, C.J., Dise, N.B., Gowing, D.J., Mountford, J.O., 2006. Loss of forb diversity in relation to nitrogen deposition in the UK: regional trends and potential controls. Global Change Biology 12, 1823-1833.

Stevens, C.J., Maskell, L.C., Smart, S.M., Caporn, S.J.M., Dise, N.B., Gowing, D.J., 2009. Identifying indicators of atmospheric nitrogen deposition impacts in acid grasslands. Biological Conservation 142, 2069-2075.

Throop, H.L., Lerdau, M.T., 2004. Effects of nitrogen deposition on insect herbivory: implications for community and ecosystem processes. Ecosystems 7, 109-133.

Tilman, D., Cassman, K.G., Matson, P.A., Naylor, R., Polasky, S., 2002. Agricultural sustainability and intensive production practices. Nature 418.

Tyler, G., 2003. Some ecophysiological and historical approaches to species richness and calcicole/calcifuge behaviour - contribution to a debate. Folia Geobotanica $38,419-428$.

Van Jaarsveld, J.A., 1995. Modelling the long-term atmospheric behaviour of pollutants on various spatial scales. PhD thesis, University of Utrecht, The Netherlands.

Van Jaarsveld, J.A., 2004. The Operation Priority Substances Model. Report No. 500045001/2004. National Institute for Public Health and the Environment (RIVM), Bilthoven, The Netherlands.

Wedin, D., Tilman, D., 1996. Influence of nitrogen loading and species composition on the carbon balance of grasslands. Science 274, 1720-1723.

Weiss, S.B., 1999. Cars, cows, and checkerspot butterflies: nitrogen deposition and management of nutrient-poor grassland for a threatened species. Conservation Biology 13, 1476-1486. 